\title{
The Effect of Nitrogen, Organic, Biological Fertilizer on Quantitative and Qualitative Characteristics of Cucurbita Pepo L. in North Khorasan
}

\author{
Ismail Khojasteh Maah Saayeh
}

\begin{abstract}
In order to examine the effect of Nitrogen, Organic, Biological fertilizers on certain quantitative and qualitative attributes of cucurbita pepo L. This research was accomplished by split plot in the form of Randomized complete block design in four repetitions, at a research farm at Shirvan College of Agricultural Sciences and Natural Resources, Ferdowsi University of Mashhad, Shirvan, Iran. In this research essential factors consisted of $100 \%$ organic (2000 kg/ha decomposed cattle manure), 25\% chemical (37.5 kg/ha urea)+75\% organic (1500 kg/ha decomposed cattle manure), $50 \%$ chemical (75 kg/ha urea), $75 \%$ chemical (112.5kg/ha urea) $+25 \%$ organic (500 kg/ha decomposed cattle manure) and $100 \%$ chemical $(150 \mathrm{~kg} / \mathrm{ha}$ urea).Insemination of seed with Aztobacter and Azospirillum and non-insemination of seed with Aztobacter and Azospirillum constituted subsidiary factor. Measured attributes included the number of blossom (male and female), number of fruit in shrub, number of seed in fruit, weight of 1000 seeds, wet weight of fruit and diameter of fruit. This research findings showed that the most numbers of male blossoms have been (50.87) and female blossoms (9.375), mean weight of fruit (4.95 kg) and maximum number of seed in fruit (266/83 in shrub) have related to $50 \%$ chemical $+50 \%$ organic treatment. Also the greatest numbers of fruit in shrub (2.5), weight of 1000 seeds (192.39 g) and diameter of fruit have related to $25 \%$ chemical and $75 \%$ organic treatment.
\end{abstract}

Keywords - cucurbita pepo L, Nitrogen, Biological fertilizer, Organic fertilizer.

\section{INTRODUCTION}

One of the valuable medicinal plants (plant used in herbalism) in most of developed countries pharmaceutical industries, is cucurbita pepo L [9]. In recent years, this plant (herb) entered to flora of Iran. Cultivation of this plant has been increasing. In recent decade, this herb is recognised as an important medicinal source. Also, it has appropriate economic value. Seeds of this herb include oil, fatty acid, phytosterol, Carotenoids and A.E vitamins. Medicines for curing prostate hyperplasia, Dysuria (painful urination), alimentary tract regulation, hardening of the arteries (atherosclerosis), pain alleviation of urinary tract infection are produced from seeds of Cucurbita pepo L. Peponen, Gronfing, Prostaliquid, Fosfestrol and Positron are among the medicines

Management and Planning Organization of North Khorasan manufactured from effective materials of Cucurbita pepo $\mathrm{L}$ that can be pointed out [1 \& 5].

Environmental factors, intensively affect upon herbs especially Cucurbita pepo L. in such way that rain ultimate temperature and Nitrogen fertilizer largely have effect on flowering and pollination [3]. Nitrogen is one of the important nutritious elements in plant growth. Nitrogen is needed for plants in great amounts so that is base to development of Protein and Nucleic acid. Nitrogen is provided and consumed in the form of Chemical fertilizer. Nitrogen supply through extensive consuming of chemical fertilizers is one of the main reasons on water flow pollution in nature. Therefore it is necessary to avoid from harmful and negative pressure in environment and to improve developmental plans that satisfy needs for plant fertilizers. Improvement of soil quality can be evaluated on the base of its general biological qualitative and quantitative indexes. For this reason using of biological fertilizers is considered as one of the most effective management way for desirable maintenance of soil quality.

Researches have indicated that biological sources (organic) such as animal manure as fertilizer in combination with chemical fertilizer can result in soil productivity and improvement of crop productivity, because this system provides most of the plant nutritious requirements and increase efficiency of product nutritious absorption $[3,6,8]$.

\section{MATERIAL AND METHOD}

This plan was conducted in split plot in the form of Randomized complete block design in four repetitions, in research farm at Shirvan College of Agricultural Sciences and Natural Resources, Ferdowsi University of Mashhad, Shirvan branch. In this research essential factors in 5 level of fertilizers consisted of $100 \%$ organic $(2000 \mathrm{~kg} / \mathrm{ha}$ decomposed cattle manure), $25 \%$ chemical (37.5 kg/ha urea) +75\% organic (1500 kg/ha decomposed cattle manure), 50\% chemical (75 kg/ha urea), 75\% chemical (112.5kg/ha urea) + $25 \%$ organic (500 kg/ha decomposed cattle manure) and $100 \%$ chemical (150 kg/ha urea). Insemination of seed with Aztobacter and Azospirillum and non-insemination of seed with Aztobacter and Azospirillum constituted subsidiary factor. In this research, sowing was done in second half in Mars 2011. Row interval in cultivation was $140 \mathrm{~cm}$. Every 
row included 16 at distance of $40 \mathrm{~cm}$, every plot contained 4 rows of cultivation and interval between next plots in each block $250 \mathrm{~cm}$ and interval between blocks was $3 \mathrm{~m}$. urea chemical fertilizer diffused at flowering outset. The farming place and splits were shown in picture below.

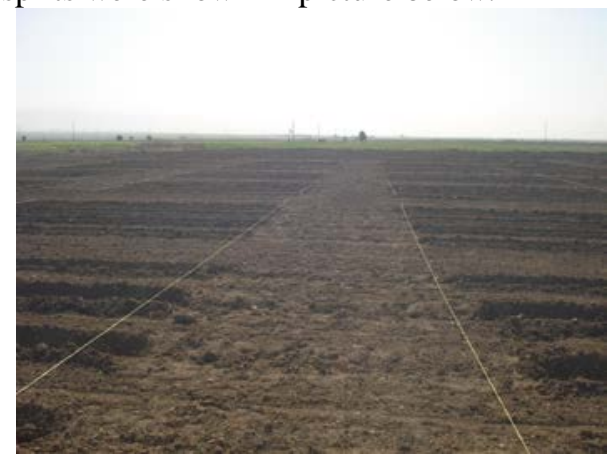

Fig. 1: split in farming place

Measured characteristics of growth included: weight of fruit, weight of 1000 seeds (by means of digital scale with accuracy of $0.1 \mathrm{~g}$ ) the number of blossom (male and female), number of fruit in shrub (by numbering in shrubs level), number of seed in fruit (numeration of seeds in produced fruit),Diameter of fruit (by use of Coulisse. Finally all of data was analyzed by variance analysis and comparison of means was done by Duncan's multiple range test.

\section{DisCUSSION AND RESULTS}

\section{A. Analysis of Measured Quantitative and Qualitative} Characteristics in Cucurbita L

Aaccording with table 1, maximum number of male and female blossoms in shrub, respectively related to treatments using $0.25 \%$ chemical $+0.75 \%$ organic $(5.2)$, $50 \%$ chemical $+50 \%$ organic (37.266). Also maximum number of male and female blossoms in shrub was related to $50 \%$ chemical $+50 \%$ organic and respectively were 50.87 and 8.38. Largest amount of male and female blossoms in seed insemination treatment was obtained 58/5 and 6.3
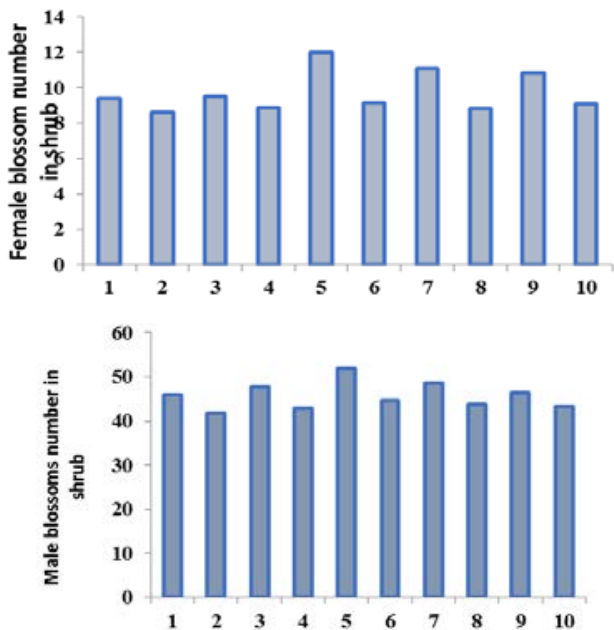

Chart 1. Mutual effects of various fertilizer treatments and seeds insemination and non-insemination with growth stimulus Bacteria on female and male blossom numbers
Maximum fruit number in shrub (2.74) related to 50\% chemical $+50 \%$ organic treatment. Also its minimum number is related to $100 \%$ chemical treatment. The reason of minimum number formation, can be related to fewer number of female blossom formation in shrub. Seed number attribute is controlled by genetic characteristics and nitrous supplies during formation procedures of seed. In mutual effects, findings showed that $50 \%$ chemical $+50 \%$ organic treatment alongside insemination with growth stimulus Bacteria, had produced maximum seed number in fruit by 287.5. This result indicate positive effect on growth stimulus bacteria on seed number (see chart 2 and picture 2).

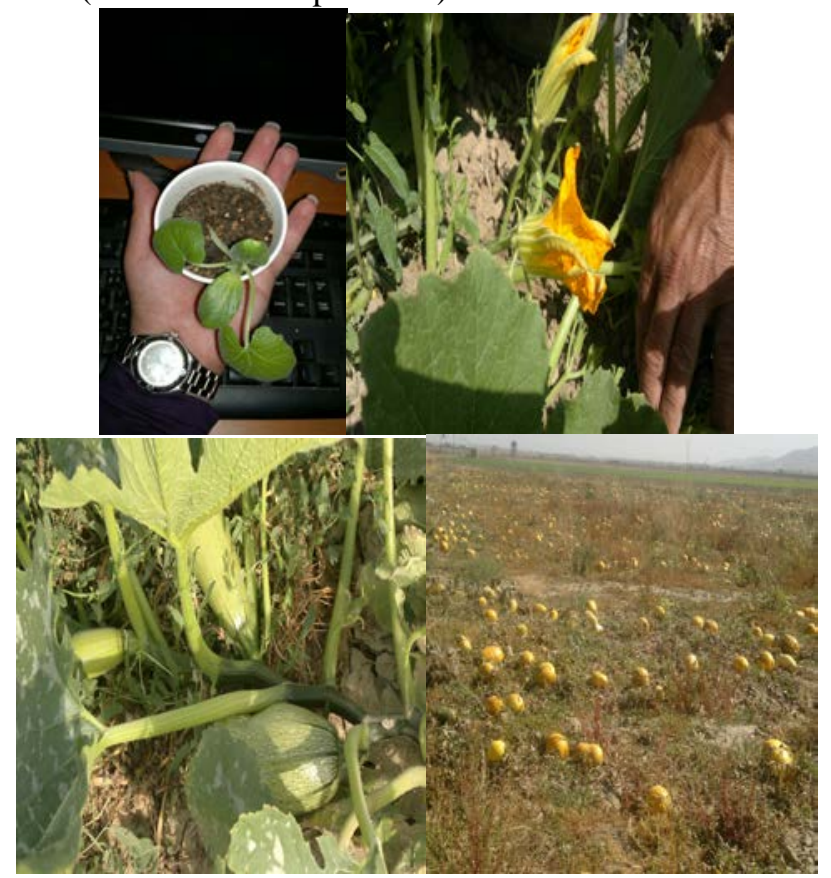

Fig. 2 blossom (two left pic) \& fruit number in shrub (two right pic)
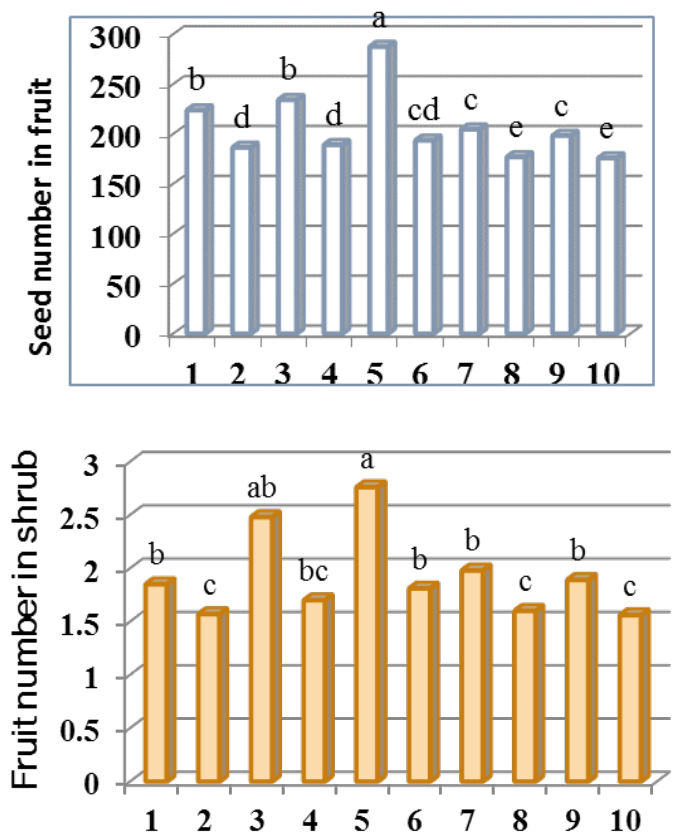

Chart 2. Mutual effects of various fertilizer treatments and seeds insemination and non-insemination with growth stimulus 
Bacteria on seed number in shrub and on fruit number in shrub Maximum amount of fruit weight is related to treatment of $75 \%$ chemical+25 \%organic with $2.51 \mathrm{~kg}$. Also in using or not using of biological fertilizers, insemination with growth stimulus bacteria treatment has been more prominent. About using or not using of biological fertilizers, insemination with growth stimulus bacteria treatment in comparison to noninsemination treatment, has produced larger fruit diameter by amount of $1.21 \mathrm{~cm}$. Therefor maximum rate of fruit diameter is related to $25 \%$ chemical $+75 \%$ organic treatment and it is $21 \mathrm{~cm}$.
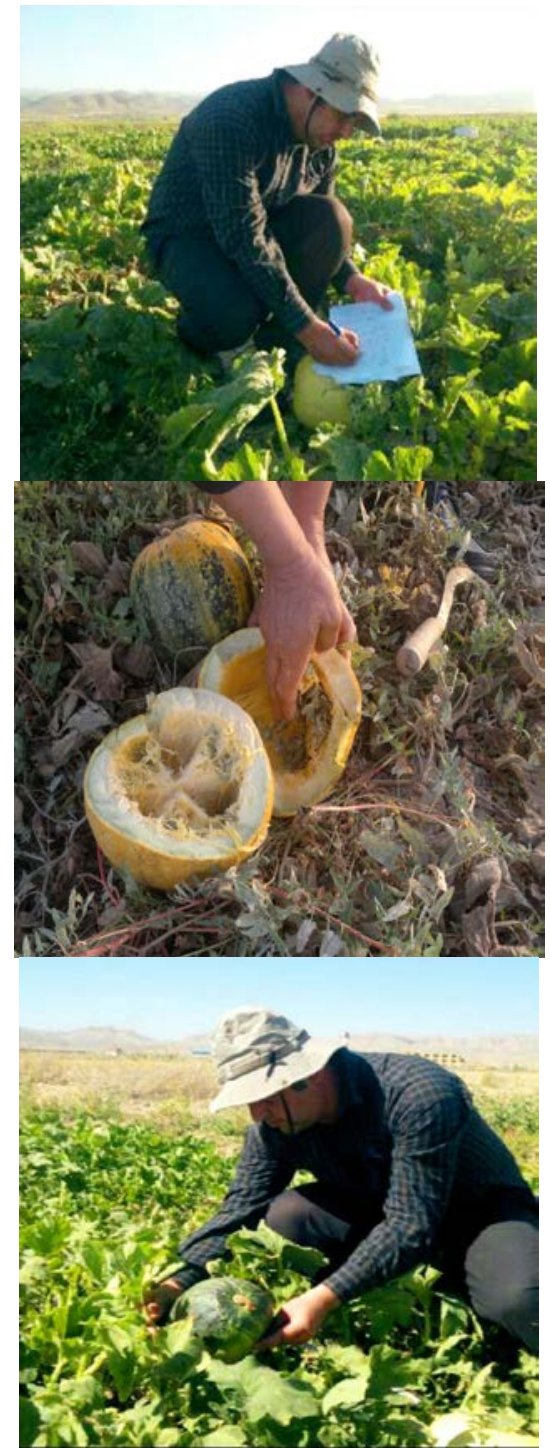

Fig. 3. Seed number in fruit $\&$ fruit diameter
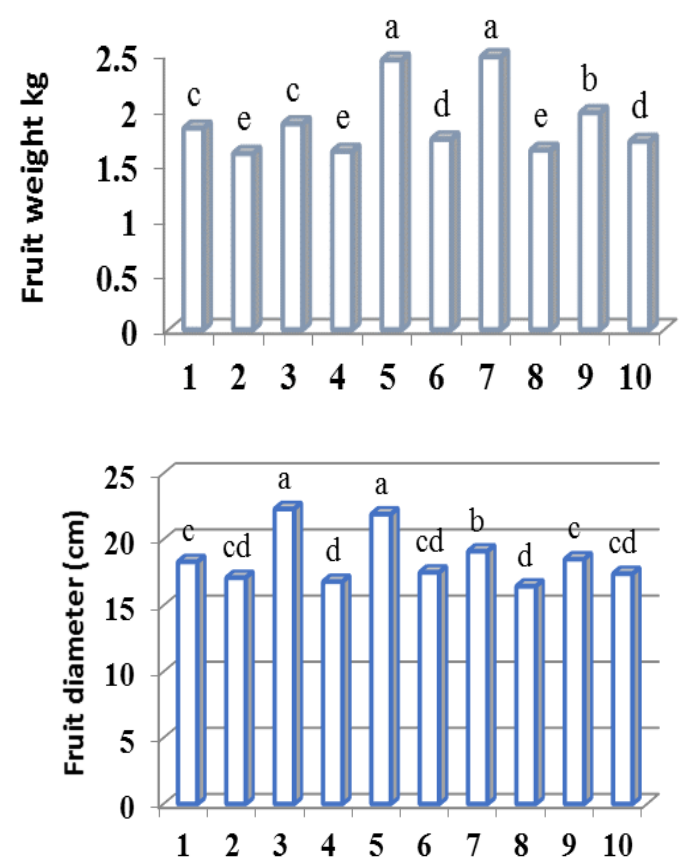

Chart 3. Mutual effects of various fertilizer treatments and seeds insemination and non-insemination with growth stimulus Bacteria on fruit weight (right chart) and fruit diameter (left chart)

Variance analysis results show that significance levels in mutual effects of various fertilizer treatments and seeds insemination and non-insemination with growth stimulus bacteria on fruit number in shrub were $\mathrm{P} \leq 01.0, \mathrm{P} \leq 05.0$. Also seed number in fruit was significant at $\mathrm{P} \leq 01.0$ level, fruit weight was significant at $\mathrm{P} \leq 01.0, \mathrm{P} \leq 05.0$ levels and fruit diameter was significant at $\mathrm{P} \leq 01.0$ level. Table I and II respectively, show the compression of main effects means of various fertilizer treatments and seeds insemination and noninsemination on measured characteristics and Variance analysis of quantitative and qualitative function and components function in cucurbia pepo L. 


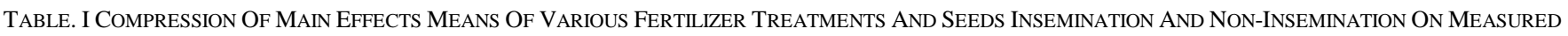
CHARACTERISTICS

\begin{tabular}{|c|c|c|c|c|c|c|c|}
\hline Factor & $\begin{array}{l}\text { Male } \\
\text { blossom } \\
\text { number in } \\
\text { shrub }\end{array}$ & $\begin{array}{l}\text { Female } \\
\text { blossom } \\
\text { number in } \\
\text { shrub }\end{array}$ & $\begin{array}{l}\text { Fruit } \\
\text { number in } \\
\text { shrub }\end{array}$ & $\begin{array}{l}\text { Seed } \\
\text { number in } \\
\text { fruit }\end{array}$ & $\begin{array}{l}\text { Fruit } \\
\text { diameter } \\
(\mathrm{cm})\end{array}$ & $\begin{array}{l}\text { Mean of } \\
\text { fruit wet } \\
\text { weight (kg) }\end{array}$ & $\begin{array}{l}\text { Weight of } \\
1000 \text { seeds }\end{array}$ \\
\hline \multicolumn{8}{|l|}{ Treatment of fertilizers } \\
\hline $100 \%$ organic & $40 \mathrm{c}$ & $6.37 \mathrm{bc}$ & $91.1 \mathrm{c}$ & $75.215 \mathrm{c}$ & $87.17 \mathrm{~b}$ & $78.1 \mathrm{c}$ & $2.148 \mathrm{c}$ \\
\hline $25 \%$ chemical $+75 \%$ organic & 41.5 bc & 6.4 bc & $51.2 \mathrm{~b}$ & $5.238 \mathrm{~b}$ & $21 \mathrm{a}$ & $98.1 \mathrm{~b}$ & 1.152 bc \\
\hline $50 \%$ chemical $+50 \%$ organic & $50.87 \mathrm{a}$ & $8.37 \mathrm{a}$ & $74.2 \mathrm{a}$ & $37.266 \mathrm{a}$ & $75.20 \mathrm{a}$ & $5.2 \mathrm{a}$ & 34.167 a \\
\hline 75\% chemical+ 25\%organic & $43.1 \mathrm{~b}$ & $6.56 \mathrm{~b}$ & $81.1 \mathrm{c}$ & $37.233 \mathrm{bc}$ & $125.18 b$ & $51.2 \mathrm{a}$ & 89.165 a \\
\hline $\begin{array}{l}100 \% \text { chemical } \\
\text { Insemination \& non insemination }\end{array}$ & $42.5 \mathrm{~b}$ & $6.5 \mathrm{~b}$ & $74.1 \mathrm{c}$ & $1.190 \mathrm{~b}$ & $25.17 b$ & $84.1 \mathrm{c}$ & $2.165 \mathrm{~b}$ \\
\hline $\begin{array}{l}\text { Insemination of seed with } \\
\text { Azospirillum \& Aztobacter }\end{array}$ & $58.5 \mathrm{a}$ & $8.8 \mathrm{a}$ & $3.2 \mathrm{a}$ & 259 a & $1.21 \mathrm{a}$ & $46.2 \mathrm{a}$ & 23.165 a \\
\hline $\begin{array}{l}\text { Non- insemination of seed with } \\
\text { Azospirillum \& Aztobacter }\end{array}$ & $40.7 b$ & $6.3 \mathrm{~b}$ & $57.1 \mathrm{~b}$ & $35.191 \mathrm{~b}$ & $9.16 b$ & $67.1 \mathrm{~b}$ & $49.137 \mathrm{~b}$ \\
\hline
\end{tabular}

TABLE. II. VARIANCE ANALYSIS OF QUANTITATIVE AND QUALITATIVE FUNCTION AND COMPONENTS FUNCTION IN CUCURBIA PEPO L

\begin{tabular}{|c|c|c|c|c|c|c|c|c|}
\hline Factor & $\begin{array}{l}\text { Degree of } \\
\text { freedom }\end{array}$ & $\begin{array}{l}\text { Male } \\
\text { blossom } \\
\text { number in } \\
\text { shrub }\end{array}$ & $\begin{array}{l}\text { Female } \\
\text { blossom } \\
\text { number in } \\
\text { shrub }\end{array}$ & $\begin{array}{c}\text { Fruit } \\
\text { number in } \\
\text { shrub }\end{array}$ & $\begin{array}{l}\text { Seed number in } \\
\text { fruit }\end{array}$ & $\begin{array}{l}\text { Fruit } \\
\text { diameter } \\
(\mathrm{cm})\end{array}$ & $\begin{array}{c}\text { Mean of } \\
\text { fruit wet } \\
\text { weight } \\
(\mathrm{kg})\end{array}$ & $\begin{array}{l}\text { Weight of } \\
1000 \\
\text { seeds }\end{array}$ \\
\hline Repetition & 3 & 6.82 & 169 & 0.1583 & 349.985 & 2.33 & 0.587 & 3583 \\
\hline Fertilizer treatments & 4 & $775.207 * *$ & $9.725 * *$ & $2.537 * *$ & $9743.912 * *$ & $24.312^{* *}$ & $1.652 * *$ & $2061^{* *}$ \\
\hline Standard error & 12 & 108.4 & 6.742 & 0.054 & 386.896 & 1.312 & 0.362 & 1979 \\
\hline Insemination \& non insemination & 1 & $25.1452 * *$ & $5.62 * *$ & $4.225^{* *}$ & $45765.225^{* *}$ & $176.4^{* *}$ & $5.55^{*}$ & $21378 * *$ \\
\hline $\begin{array}{l}\text { Mutual effect of fertilizer } \\
\text { treatment with insemination and } \\
\text { non-insemination }\end{array}$ & 4 & $15.29^{* *}$ & $10.2^{* *}$ & $0.538^{*}$ & $3339.287^{* *}$ & $6.212^{*}$ & $0.575^{*}$ & $1184^{*}$ \\
\hline b error & 15 & 99.2 & 2.033 & 0.208 & 125.142 & 0.717 & 0.136 & 1694 \\
\hline
\end{tabular}

Findings from mean compression (see table III) show that maximum rate of shrub height is related to $50 \%$ chemical +50 \%organic treatment and its rate has been $3 \mathrm{~m}$. maximum nodes number in shrub and maximum leaves number in shrub is related to $50 \%$ chemical $+50 \%$ organic treatment which were respectively 3.25 and 9.28. Maximum rate of leaf dry weight and maximum rate of subsidiary stems number in shrub are related to $50 \%$ chemical $+50 \%$ organic treatment and their rate has been respectively, 5.44 and 3.75. Regarding with using or not using of biological fertilizers, insemination with growth stimulus bacteria treatment in comparison to non-insemination treatment, has produced higher rates in shrub height $(2.64 \mathrm{~m})$, in nodes number in brush (1.26), in leaves number in shrub (28.1), in rate of leaf dry weight $(4.40 \mathrm{~g})$ and finally in rate of subsidiary stems number in shrub with number of 3.64. Thus in the case of simultaneous using of $50 \%$ chemical $+50 \%$ organic treatment and seed insemination, maximum leaves number in shrub obtained 34.3. Maximum rateof leaf dry weigh, in simultaneous using of $50 \%$ chemical $+50 \%$ organic treatment and seed insemination was obtained $1.40 \mathrm{~g}$. At last about subsidiary stems number in shrub, maximum number in simultaneously using $50 \%$ chemical $+50 \%$ organic treatment with seeds insemination was 1.4. Variance analysis results (table IV) show that various fertilizer treatment and insemination with biological fertilize have significant effect on shrub height $(\mathrm{P} \leq$ 01.0, $\mathrm{P} \leq 05.0$ ) but mutual effects of various fertilizer treatments and seeds insemination and non-insemination growth stimulus bacteria on shrub height were not significant. various fertilizer treatment and insemination with biological fertilize have significant effect on node number in shrub ( $\mathrm{P} \leq$ 01.0), but mutual effects of various fertilizer treatments and seeds insemination and non-insemination growth stimulus bacteria on node number in shrub were not significant. Various fertilizer treatment and insemination with biological fertilize also their mutual effects have significant effect on number of leaf in shrub $(P \leq 01.0)$. At last various fertilizer treatment and insemination with biological fertilizer also their mutual effects have significant effect on leaf dry weight in shrub and on subsidiary stem number in shrub. Chart4 and picture4 indicate mentioned materials.

Oil increasing is main goal of producing oil seed. Computed results from variance analysis show that various fertilizer treatments and insemination with biological fertilizers and also their mutual effect have significant effect in oil percentage $(\mathrm{P} \leq 01.0)$. As table $3 \& 4$ indicate maximum percentage of oil has been related to $100 \%$ organic treatment and its rate has been $46.6 \%$. Regarding with using or not using of biological fertilizers, insemination with growth stimulus Bacteria treatment in comparison to no-insemination treatment, has produced larger oil percentage (47.6\%). Maximum percentage of seed oil in simultaneous using of $50 \%$ chemical $+50 \%$ organic treatment and seeds insemination has been $48.3 \%$. 
TABLE. III. COMPRESSION OF MAIN EFFECTS MEANS OF VARIOUS FERTILIZER TREATMENTS AND SEEDS INSEMINATION AND NON-INSEMINATION ON MEASURED

\begin{tabular}{|c|c|c|c|c|c|c|c|c|}
\hline \multicolumn{9}{|c|}{ CHARACTERISTICS } \\
\hline Factor & $\begin{array}{l}\text { Shrub } \\
\text { height }\end{array}$ & $\begin{array}{l}\text { Node } \\
\text { number in } \\
\text { shrub }\end{array}$ & $\begin{array}{l}\text { Leaf } \\
\text { number in } \\
\text { shrub } \\
\end{array}$ & $\begin{array}{l}\text { Leaf dry } \\
\text { weight in } \\
\text { shrub (gr) }\end{array}$ & $\begin{array}{l}\text { Subsidiary } \\
\text { stem number in } \\
\text { shrub }\end{array}$ & $\begin{array}{l}\text { Fruit } \\
\text { function } \\
\text { (to/ha) } \\
\end{array}$ & $\begin{array}{l}\text { Seed } \\
\text { function } \\
\text { (gr/to) }\end{array}$ & Oil percent \\
\hline \multicolumn{9}{|l|}{ Treatment of fertilizers } \\
\hline $100 \%$ organic & $98.1 b$ & $8.23 c$ & $1.22 \mathrm{c}$ & $2.30 \mathrm{~d}$ & $3.2 \mathrm{c}$ & $8.14 \mathrm{~d}$ & $8.15 \mathrm{~d}$ & $4.46 a$ \\
\hline $25 \%$ chemical $+75 \%$ organic & $84.2 \mathrm{ab}$ & $3.24 b$ & $8.23 \mathrm{bc}$ & $6.34 c$ & $05.3 b$ & $8.18 b$ & $45.20 \mathrm{~b}$ & $3.44 \mathrm{~b}$ \\
\hline $50 \%$ chemical $+50 \%$ organic & За & $1.26 \mathrm{a}$ & $9.28 \mathrm{a}$ & $5.44 \mathrm{a}$ & $57.3 a$ & $54.22 \mathrm{a}$ & 7.26 a & $8.43 \mathrm{~b}$ \\
\hline $75 \%$ chemical+ $25 \%$ organic & $49.2 \mathrm{ab}$ & $1.25 \mathrm{bc}$ & $1.25 b$ & $22.38 b$ & $52.3 \mathrm{a}$ & $3.19 \mathrm{~b}$ & $3.22 b$ & $8.37 \mathrm{c}$ \\
\hline $100 \%$ chemical & $17.2 \mathrm{~b}$ & $9.24 \mathrm{bc}$ & $3.25 b$ & $88.37 \mathrm{~b}$ & $8.2 \mathrm{bc}$ & $8.16 \mathrm{c}$ & $4.17 c$ & $2.34 \mathrm{c}$ \\
\hline \multicolumn{9}{|l|}{ Insemination \& insemination } \\
\hline $\begin{array}{l}\text { Insemination of seed with } \\
\text { Azospirillum \&Aztobacter }\end{array}$ & $64.2 \mathrm{a}$ & $3.25 a$ & $1.28 \mathrm{a}$ & $4.40 \mathrm{a}$ & $64.3 \mathrm{a}$ & $8.24 \mathrm{a}$ & $3.28 \mathrm{a}$ & $6.47 \mathrm{a}$ \\
\hline $\begin{array}{l}\text { Non- insemination of seed with } \\
\text { Azospirillum \& Aztobacter }\end{array}$ & $02.2 \mathrm{~b}$ & $8.20 \mathrm{~b}$ & $0.22 \mathrm{~b}$ & $6.27 b$ & $87.2 \mathrm{~B}$ & $8.15 \mathrm{~b}$ & $9.18 \mathrm{~b}$ & $8.35 b$ \\
\hline
\end{tabular}

\begin{tabular}{lllllllll}
\multicolumn{2}{c}{ TABLE. IV. VARIANCE ANALYSIS OF QUANTITATIVE AND QUALITATIVE FUNCTION AND COMPONENT FUNCTION IN CUCURBIA PEPO L } \\
\hline \hline
\end{tabular}
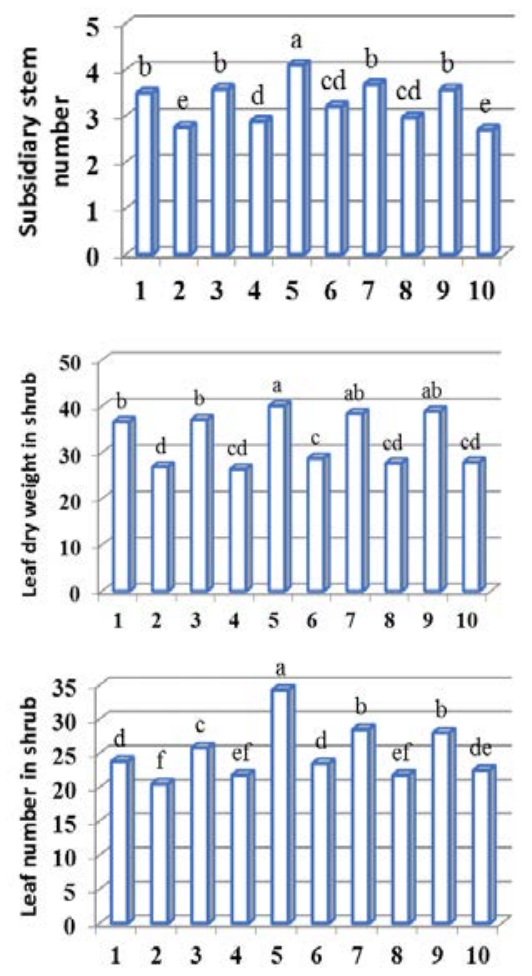

Chart 4. Mutual effects of various fertilizer treatments and seeds insemination and non-insemination with growth stimulus Bacteria on subsidiary stem number, leaf dry weight in shrub, leaf number in shrub (from left to right)

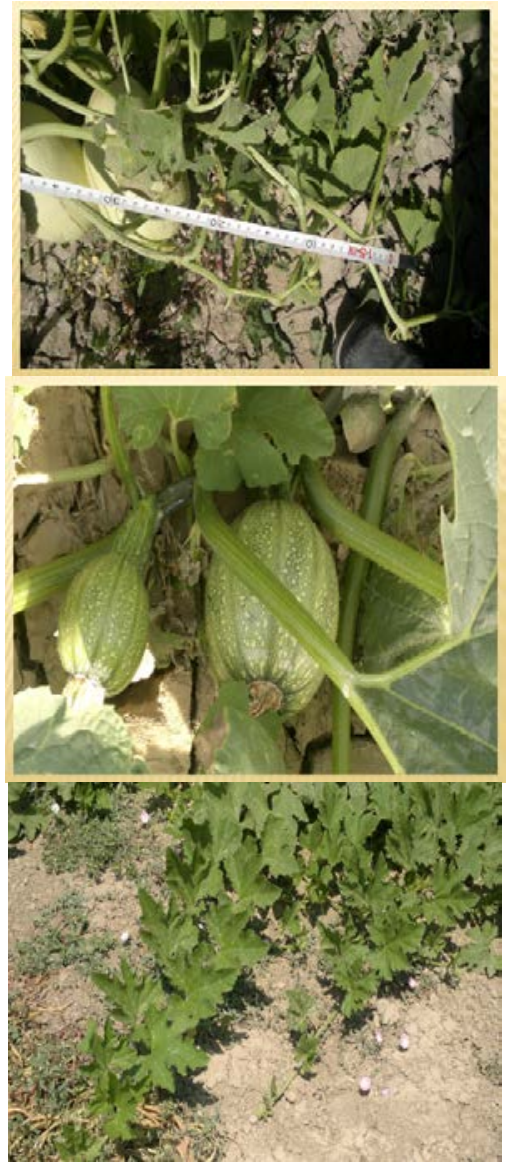

Fig. 5. Shrub height, node number in shrub, leaf number in shrub (from left to right) 


\section{CONCLUSION}

Gholipoori et al [2] in a research that during two cultivation years $(2003,2004)$ have conducted on Cucurbita pepo L. Have concluded that mean number of male blossoms during that two years have been respectively 96.43 and 24.41 number and also mean number of female blossom have been 12.11 and 73.6. Table II show that among different fertilizer treatments, there is significant difference regard to fruit number and number of seed in fruit. Generally, maximum number of fruit and number of seed in fruit, respectively related to treatments using $0.25 \%$ chemical $+0.75 \%$ organic (5.50), 50\% chemical $+50 \%$ organic (37.9). Moazzen and Daneshian [7] had done the research at 2006. They also concluded that using of nitrogen fertilizer is very important in this crop, because without using of Nitrogen fertilizer, mean of fruit number in shrub is fewer than 2 but with using nitrogen fertilizer mean of fruit number in shrub is more than 2. Also wet weight of fruit with maximum mean of 94.4 and weight of 1000 seeds 26.191 were related to treatment with $50 \%$ chemical $+50 \%$ organic. Diameter of fruit maximum with 21 was related to $25 \%$ chemical $+75 \%$ organic treatment.

Use of biological fertilizers containing Aztobacter and Azospirillum that are arbitrary stabilizers of molecular nitrogen, instead of chemical fertilizers, cause to supply nitrous requirements of plant and to increase its growth. Concerning with organic material addition to soil, firstly organic procedure and then mineralization procedure of nitrogen take place. Simultaneous combination of organic and chemical fertilizer, while supply plant Nitrogen need, because of organic chemical by decomposer bacteria of soil organic material wasting of nitrogen (leaching, evaporation or consolidation) is decreased. Therefore for the reason of mineralization procedure, nitrogen again gradually turning into absorbable form for plant and provide its need during growth of plant.

In this regard, proportion between ratios of organic to mineral form of nitrogen is very significant. According to yield results equal ratio of organic and mineral form of nitrogen, is the best ratio. Consequently results from this research indicate that use of organic fertilizers and combinational feed management including 50\% chemical + $50 \%$ organic have the most important role in function components and quantitative and qualitative function of cucurbita pepo L.

\section{REFERENCES}

[1] A. Siami and R. Heydari, and A.Dastpaak, "Assessment of Lipid Content and Studding Fatty Acid in some Varieties of Cucurbita pepo L" Agronomy Journal. vol. 59, pp. 16-19, Summer, 2011

[2] A. Golipoori, A. Javanshir, F. Rahimzade Khooi, A. Mohamadi, H. Bayat "The Effect of Nitrogen and Some Pruning on Function and Function Element of Cucurbita L.” journal of agriculture science and natural resource, vol. 13, 2005.

[3] B.R, Chandrasekar, G. Ambrose, and N. Jayabalan, "Influence of biofertilizers and nitrogen source level on the growth and yield of Echinochloa frumentacea (Roxb) Link". Journal of Agricultural Technology, Vol. 1: 2, 223-234, 2005
[4] F.S Wagner, "The Health Value of Styrian Pumpkin-Seed Oil- Scince and Fiction”. Cucurbit Genetics Cooperative. vol. 23, 122-123 .2000

[5] H. Arooie, R.Omidbeigi, and A.Kashi, "Effect of Different Nitrogen Level in some Characteristics of Cucurbita pepo L" Agronomy Journal. vol. 48, pp. 4-9, Summer 2011.

[6] S. Harveth, .and Z. Bedo. "Another Possibility inT of Hyperlipidaemia with Peponen of Natural Active Substance”. Mediflora (special issue) vol. 89, 7-8,1998

[7] Sh. Moazzen J. Daneshian, "Study of Plant Population and Phosphate Fertilization on some Agronomic Characters and Seed and Fruit Yield of Cucurbita L.”Iranian journal of medicinal and aromatic plants, vol. 22, No. 4, 2006.

[8] S. Reiners, and D.I.M Riggs, "Plant Spacing and Variety Affect Pumpkin Yield and Fruit size, but Supplemental Nitrogen does not”. Hort. Sci. Vol. 32(6):1037-1039 .1997.

[9] S.Z. Salmasi, A.javanshir, R. Omidbeigi, H. Aliari, K. G. Galazani, J. Afshareffect, "The Effect of Planting Date and Remove Irrigation on Essence of Anise” Daneshe keshavarzi , vol. 13, No. 2, pp. 47-56, Summer 2003.

[10] Obi, I.U. (2002). Statistical methods of detecting differences between treatment means and research methodology issues in laboratory and field experiments. SNAAP Press Nigeria Limited Enugu. pp. 9-46.

[11] Steel, G. and Torrie, J.H. (980). Procedure of statistics. A biometrical approach (2nd edition) New York. Megrow Hill Box colpeny Inc. p. 633. 